\title{
In Vivo and In Vitro Studies of Urinary Concentrating Ability in Potassium-depleted Rabbits
}

Kent H. Raymond, Karen K. Davidson, and Thurman D. McKinney

Department of Medicine, Division of Nephrology, University of Texas Health Science Center and Medical and Research Services, Audie L. Murphy Veterans Hospital, San Antonio, Texas 78284

\section{Abstract}

The factors responsible for the urinary concentrating defect associated with the potassium-depleted (KD) state are uncertain. The present studies were designed to, first, determine whether a urinary concentrating defect exists in potassium-depleted rabbits and, second, to use the technique of in vitro perfusion to evaluate directly the antidiuretic hormone (ADH) responsiveness of cortical collecting tubules (CCT) in this setting. Feeding female New Zealand White rabbits a potassiumdeficient diet for 2 wk caused a significant fall in plasma potassium levels in both the ad-libitum and controlled water intake groups $(P<0.001)$. Muscle potassium content after 2 wk of potassium restriction fell from $45.6 \pm 0.9$ to $29.0 \pm 1.2$ meq/100 $\mathrm{g}$ fat-free dry solids $(P<0.001)$. Renal papillary sodium content fell significantly from a control value of $234.6 \pm 8.0$ to $182.46 \pm 10.0 \mathrm{meq} / \mathrm{kg} \mathrm{H}_{2} \mathrm{O}$ after 2 wk of potassium restriction.

Maximal urinary osmolality measured after $12 \mathrm{~h}$ of dehydration and $1.25 \mathrm{U}$ pitressin IM was significantly decreased in rabbits after 2 wk of potassium restriction in both the adlibitum and controlled water intake groups $(P<0.001)$. The relationship between plasma potassium concentration and maximum urinary osmolality was significantly correlated in both the ad-libitum and controlled water intake groups, $r=0.73$ and $0.68(P<0.001)$, respectively. In addition, refeeding $\mathrm{KD}$ rabbits with normal chow for 1 wk resulted in normalization of both plasma potassium levels and urinary concentrating ability.

CCT from control and $\mathrm{KD}$ rabbits were perfused in vitro at $25^{\circ} \mathrm{C}$. The hydraulic conductivity coefficient, Lp, was significantly reduced at all doses of $\mathrm{ADH}$ tested in tubules from KD rabbits when compared with control tubules. In addition, the maximal hydraulic conductivity in tubules from KD rabbits when tested with $200 \mu \mathrm{U} / \mathrm{ml} \mathrm{ADH}$ at $37.5^{\circ} \mathrm{C}$ was only $23 \%$ of control values $(P<0.05)$. Furthermore, this reduced ADH responsiveness persisted when the bath potassium was elevated from 5 to $20 \mathrm{mM}$. The reflection coefficient for $\mathrm{NaCl}$ when

Portions of this work were presented at the annual meeting of the American Federation for Clinical Research, Washington, DC, 5 May 1984; the IXth International Congress of Nephrology, Los Angeles, CA, 12 June 1984; and the annual meeting of the Southern Section of the American Federation for Clinical Research, New Orleans, LA, 30 January 1985.

Address correspondence to Dr. Raymond, Department of Medicine, Division of Nephrology, The University of Texas Health Science Center, 7703 Floyd Curl Drive, San Antonio, TX 78284.

Received for publication 21 May 1984.

J. Clin. Invest.

(C) The American Society for Clinical Investigation, Inc.

0021-9738/85/08/0561/06 \$1.00

Volume 76, August 1985, 561-566 compared with raffinose was 0.91 in tubules from $\mathrm{KD}$ animals. Thus, these data suggest that the ADH-resistant urinary concentrating defect associated with potassium depletion is due, at least in part, to a diminished responsiveness of the CCT to ADH.

Therefore, further studies were designed to investigate the cellular steps involved in this abnormal response. There was no difference in the 8-para-chlorophenylthio cyclic AMP induced hydroosmotic response between CCT from KD and control rabbits. Since the cAMP-induced hydroosmotic response was similar between KD and control CCT, experiments were performed to evaluate the contribution of phosphodiesterase (PDIE) activity by using the potent PDIE inhibitor isobutylmethylxanthine $\left(10^{-4}\right.$ and $\left.10^{-3} \mathrm{M}\right)$ in the presence of $\mathrm{ADH}(200 \mathrm{U} / \mathrm{ml})$. Although Lp was increased by PDIE inhibition in CCT from both control and KD animals, the overall hydroosmotic response in CCT from KD rabbits was still significantly reduced when compared with controls. The final experiments used forskolin to evaluate further the adenylate cyclase complex. The resulting hydroosmotic response in CCT from $\mathrm{KD}$ rabbits was almost identical to that obtained in controls. In conclusion, these data suggest that the decreased responsiveness of CCT from KD rabbits to ADH involves a step at or proximal to the stimulation of the catalytic subunit of adenylate cyclase, and that PDIE activity makes no contribution to this abnormal hydroosmotic response.

\section{Introduction}

Polyuria is just one of many abnormalities of renal function that has been associated with the potassium-depleted state (1). In 1957, Hollander and associates (2) showed that the polyuria of potassium depletion (KD) ${ }^{1}$ was associated with a defect in renal concentrating ability that was not corrected by administrating antidiuretic hormone (ADH) (2). Since then several mechanisms have been proposed to explain this defect, including insensitivity to $\mathrm{ADH}(3)$, decreased papillary solute content (4), prostaglandin overproduction (5), primary polydipsia (6), abnormal medullary oxidative metabolism (7), and altered ADH release (8).

The fact that $\mathrm{KD}$ animals exhibit a submaximal renal response to exogenously administered $\mathrm{ADH}$ has encouraged a considerable amount of investigation. Earlier studies using heterogenous kidney tissue preparations from KD rats showed a defect in ADH-stimulated adenylate cyclase activity and cyclic adenosine-3',5'-monophosphate (cAMP) accumulation

1. Abbreviations used in this paper: 8-p-CPT-cAMP, 8-para-chlorophenylthio-cyclic AMP; ADH, antidiuretic hormone; C, control; CCT, cortical collecting tubules; DOCA, desoxycorticosterone acetate; FFDS, fat-free dry solids; IBMX, isobutylmethylxanthine; Jv, rate of water absorption; KD, potassium depletion (depleted); Lp, hydraulic conductivity coefficient; $V_{0}$, rate of perfusion. 
in the medullary and papillary regions of the kidney $(9,10)$. Although Kim et al. (11) showed that isolated medullary thick ascending limbs of Henle and outer medullary collecting tubules from $\mathrm{KD}$ rats had normal and increased ADH-sensitive cAMP accumulation, respectively (11), more recent studies from $\mathrm{Kim}$ et al. showed decreased cAMP accumulation in inner medullary collecting ducts from $\mathrm{KD}$ rats (12). Although these studies and ones in amphibian urinary bladders (13) indirectly suggest that an impaired hydroosmotic response to $\mathrm{ADH}$ exists in $\mathrm{KD}$ animals, the exact location along the nephron and the underlying mechanism responsible for the urinary concentrating defect remain to be shown conclusively.

Since previous studies have shown that an abnormal renal response to $\mathrm{ADH}$ exists in $\mathrm{KD}$ animals, the present study was designed to investigate directly by isolated tubular perfusion the ADH-stimulated hydroosmotic response of cortical collecting tubules (CCT) from $\mathrm{KD}$ rabbits. The CCT was investigated for several reasons, including the exquisite sensitivity of this segment to ADH and CAMP (14), the relatively larger magnitude of water reabsorption in this segment compared with the medullary collecting tubule (15), the existence of ADH-stimulated prostaglandin production (16), the demonstration of prostaglandin inhibition of ADH-induced CCT water reabsorption (17), and the presence of morphologic changes in this segment during potassium depletion (18). Finally, water reabsorption in the CCT is an essential determinant of inner medullary urea reabsorption and the overall maintenance of medullary interstitial hypertonicity.

\section{Methods}

Female New Zealand White rabbits weighing 1.5 to $2.5 \mathrm{~kg}$ were fed a potassium-deficient diet containing $\sim 1 \mathrm{meq} / \mathrm{kg}$ potassium, $437 \mathrm{meq} /$ $\mathrm{kg}$ sodium, and supplemented with $2.4 \mathrm{~g} / \mathrm{kg}$ of magnesium (ICN Nutritional Biochemicals, Cleveland, $\mathrm{OH}$ ). The control animals were fed regular laboratory rabbit chow containing $354 \mathrm{meq} / \mathrm{kg}$ potassium, $130 \mathrm{meq} / \mathrm{kg}$ sodium, and $2.4 \mathrm{~g} / \mathrm{kg}$ magnesium (Wayne Feed Division, Continential Grain Co., Chicago, IL). Rabbits were divided into two groups according to their water intake, either ad-libitum or limited to $110 \mathrm{ml} / \mathrm{d}$ (an amount similar to that ingested ad-libitum while ingesting the control diet). The animals were maintained on this regimen for 2 wk during which time weekly determinations of body weight, urine flow rate, and plasma potassium levels (Klina Flame, Beckman Instruments, Inc., Fullerton, CA) were performed. The animals neither gained nor lost significant weight during the 2 wk of potassium restriction. Urinary flow rates increased in the ad-libitum group from $6.3 \pm 0.9$ to $10.2 \pm 1.1$ and $9.1 \pm 1.4 \mathrm{ml} / \mathrm{h}$ after 1 and $2 \mathrm{wk}$, respectively. The plasma potassium concentration fell significantly over the 2-wk period from $4.7 \pm 0.2$ to $2.3 \pm 0.03 \mathrm{meq} / \mathrm{liter}(P<0.001, n=15)$ in the ad-libitum group. Similar changes were seen in the controlled intake group (4.8 \pm 0.2 to $2.2 \pm 0.1 \mathrm{meq} / \mathrm{liter}(P<0.001, n=12)$.

Tissue potassium levels were measured in psoas muscle samples obtained after decapitation and frozen until the time of analysis. In preparation for analysis, the muscle samples were lyophilized, extracted with anhydrous ether, and weighed. The tissue was then digested in concentrated nitric acid ( $1 \mathrm{ml} / 100 \mathrm{mg}$ tissue) for at least $24 \mathrm{~h}$ at room temperature. The $\mathrm{pH}$ of the solutions was adjusted to 7.8 by adding ammonium hydroxide, and the volumes were brought up to $25 \mathrm{ml}$ in volumetric flasks by adding distilled, deionized water. The sodium and potassium concentrations of the solutions were determined by flame photometry and the results were expressed as meq of potassium per $100 \mathrm{~g}$ of fat-free dry solids (FFDS). The muscle potassium content fell significantly from $45.6 \pm 0.9 \mathrm{meq} / 100 \mathrm{~g}$ FFDS in 11 control animals to $29.0 \pm 1.2 \mathrm{meq} / 100 \mathrm{~g}$ FFDS $(P<0.001)$ in 26 experimental animals over the 2 -wk period.

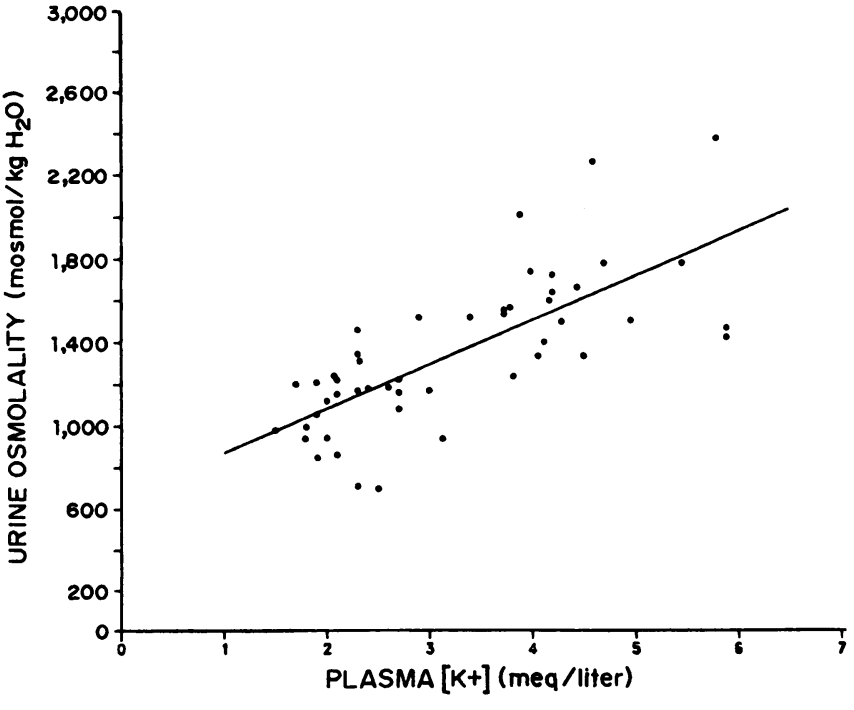

Figure 1. Correlation between plasma $\left[\mathrm{K}^{+}\right]$and maximal urine osmolality in rabbits on a $\mathrm{K}^{+}$-free diet and ad-libitum $\mathrm{H}_{2} \mathrm{O}$ intake. $Y$ $=211.47 x+659.92 ; r=0.73 ; n=49 ; P<0.001$.

Renal papillary sodium content was analyzed in control and $\mathrm{KD}$ rabbits. Papillae were resected, weighed, lyophilized to dry weight, reweighed, digested in nitric acid, neutralized with ammonium hydroxide, and volumes were brought up to $1 \mathrm{ml}$ before analysis by flame photometry. The renal papillary sodium content decreased significantly from $234.6 \pm 8.0 \mathrm{meq} / \mathrm{kg} \mathrm{H}_{2} \mathrm{O}$ in 12 control animals to $182.5 \pm 10.0 \mathrm{meq} / \mathrm{kg} \mathrm{H} \mathrm{H}_{2} \mathrm{O}(P<0.001)$ in 13 experimental animals.

The urinary concentrating ability of control and $\mathrm{KD}$ animals was measured initially and after 1 and 2 wk on their respective diets. After $12 \mathrm{~h}$ of water deprivation, animals were given an intramuscular injection of $1.25 \mathrm{U}$ of pitressin tannate in oil (Pitressin, Parke-Davis Co., Div. Warner-Lambert Co., Morris Plains, NJ). Urine was obtained $8 \mathrm{~h}$ later by urethral catheterization and its osmolality was determined by freezing point depression (Osmette; Precision Systems, Inc., Natick, MA). Maximal urinary osmolality fell significantly from $1,655 \pm 64$ to $1,130 \pm 47 \mathrm{mOsm} / \mathrm{kg} \mathrm{H}_{2} \mathrm{O}(P<0.01, n=25)$ in the ad-libitum group after 2 wk; similar changes were seen in the controlled water intake group $\left(2,086 \pm 139\right.$ to $1,158 \pm 81 \mathrm{mOsm} / \mathrm{kg} \mathrm{H}_{2} \mathrm{O}(P<0.05, n=12)$. As shown in Figs. 1 and 2, maximal urinary osmolality was correlated with the plasma potassium concentration in both ad-libitum and controlled water intake groups. ${ }^{2}$ Potassium repletion was achieved by refeeding $6 \mathrm{KD}$ rabbits regular laboratory chow for 1 wk. The plasma potassium levels and urinary concentrating ability normalized after this maneuver ( $\left[\mathrm{K}^{+}\right]$, after refeeding, $4.31 \pm 0.19$; vs. control, $4.30 \pm 0.13$ meq/liter; Uosm, after refeeding, $1,873 \pm 95$ vs. control, $1,750 \pm 96$ $\mathrm{mOsm} / \mathrm{kg} \mathrm{H}_{2} \mathrm{O}$ ).

In vitro perfusion studies. Cortical collecting tubules were isolated and perfused in vitro according to the technique developed by Burg (19) and as used previously $(20,21)$. After decapitation of the rabbit, the kidneys were quickly removed and tubules were dissected from 2$3 \mathrm{~mm}$ cross-sectional slices immersed in chilled bath solution containing

2. Since hypoaldersteronism is often associated with potassium depletion and previous workers have shown that the urinary concentrating defect associated with adrenal insufficiency in the rabbit is correctable by the administration of either dexamethasone or desoxycorticosterone acetate (26), desoxycorticosterone acetate (DOCA) $(250 \mu \mathrm{g} / \mathrm{kg}$ IM) was subsequently administered to five $\mathrm{KD}$ rabbits after $12 \mathrm{~h}$ of dehydration and stimulation with $1.25 \mathrm{U}$ pitressin tannate in oil. The urine osmolality did not increase after DOCA and remained significantly reduced when compared with the control values in the same animals before the induction of $\mathrm{KD}$ (post pitressin and DOCA, $903 \pm 84$ vs. control, $1,718 \pm 111, P<0.025, n=5)$. 


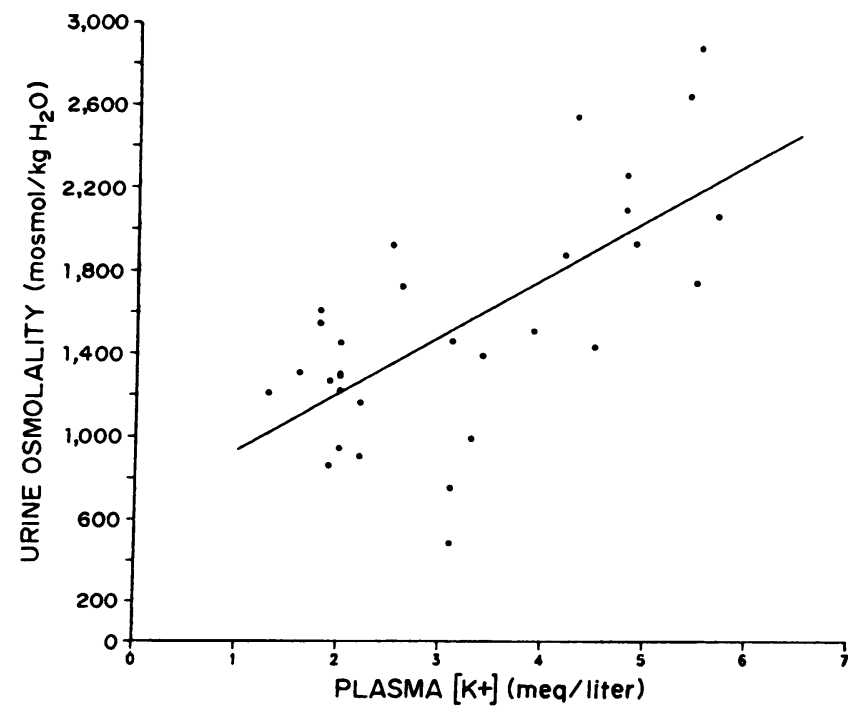

Figure 2. Correlation between plasma $\left[\mathrm{K}^{+}\right]$and maximal urine osmolality in rabbits on a $\mathrm{K}^{+}$-free diet and controlled $\mathrm{H}_{2} \mathrm{O}$ intake. $Y$ $=275.06 x+658.84 ; r=0.68 ; n=31 ; P<0.001$.

(in $\mathrm{mM}$ ): sodium chloride, 139; magnesium sulfate, 1.2; calcium chloride, 2.0; dibasic potassium phosphate, 2.5 ; glucose, 5.5; L-alanine, 6.0; sodium lactate, 4.0; and sodium citrate, 1.0. The mean tubular length was $1.31 \pm 0.19 \mathrm{~mm}(n=49)$.

ADH dose response. The ADH dose-response curves of CCT from control $(\mathrm{C})$ and $\mathrm{KD}$ rabbits were determined by perfusing against a transtubular gradient of $200 \mathrm{mOsm} / \mathrm{kg} \mathrm{H}_{2} \mathrm{O}$ at $25^{\circ} \mathrm{C}$. The perfusion fluid contained carboxyl- $\left[{ }^{14} \mathrm{C}\right]$ inulin (New England Nuclear, Boston, MA) as a volume marker and was identical to the bath except for the sodium chloride concentration, which was reduced to $25 \mathrm{mM}$. The bath solution as described above and perfusate were bubbled with $100 \% \mathrm{O}_{2}$ and adjusted to $\mathrm{pH} 7.4$ with $0.1 \mathrm{~N} \mathrm{HCl}$ or $0.1 \mathrm{~N} \mathrm{NaOH}$. The bath was continuously exchanged at a rate of $0.5 \mathrm{ml} \cdot \mathrm{min}^{-1}$. Tubules were allowed to equilibrate for $150 \mathrm{~min}$ after decapitation before collecting at least three control samples over a 20-min period. After this, ADH (Pitressin, Parke-Davis Co.) in concentrations of 10, 100,200 , and $400 \mu \mathrm{U} / \mathrm{ml}$ was sequentially added to the bath. Again, three samples were collected at each different $\mathrm{ADH}$ concentration after a 10-min interval to allow for complete bath exchange and tubular equilibration. The collected samples were deposited immediately into scintillation vials containing acetic acid, to which Aquasol (New England Nuclear, Boston, MA) was then added and subsequently counted on a Beckman LS-7000 scintillation counter (Beckman Instruments, Fullerton, CA). Bath samples were taken at the end of each period, placed in scintillation vials, and counted to determine the amount of leak present. The leak was $<2 \%$ of the perfusion rate in all studies.

Maximal $A D H$ response. The maximal hydroosmotic response of CCT was evaluated with $\mathrm{ADH}(200 \mu \mathrm{U} / \mathrm{ml})$ at $37.5^{\circ} \mathrm{C}$ using the same techniques, perfusate, and bath solutions as described above. Tubules were dissected, transferred to the perfusing chamber, and allowed to equilibrate for $150 \mathrm{~min}$ before three control samples were collected. ADH, $200 \mu \mathrm{U} / \mathrm{ml}$, was then added to the bath solution and samples were collected immediately and continuously for a period of $80 \mathrm{~min}$. The maximal hydroosmotic response was determined from the mean of values obtained over a 30 -min peak period.

Reflection coefficient of $\mathrm{NaCl} v$ s. raffinose. The reflection coefficient for $\mathrm{NaCl}$ was estimated by perfusing tubules with a solution (300 $\mathrm{mOsm} / \mathrm{kg} \mathrm{H}_{2} \mathrm{O}$ ) identical to the bath solution previously described. The new bath solution was similar except that it contained ADH 200 $\mu \mathrm{U} / \mathrm{ml}$ and the osmolality was increased to $500 \mathrm{mOsm} / \mathrm{kg} \mathrm{H}_{2} \mathrm{O}$ by the addition of $\mathrm{NaCl}$ or raffinose. The sequence of $\mathrm{NaCl}$ or raffinose bath exposures was alternated in every other experiment and had no effect on the tubular response to ADH.

Effect of elevated peritubular $\mathrm{K}^{+}$-concentration. The in vitro effect of an elevated bath $\mathrm{K}^{+}$concentration was evaluated by perfusing CCT in bath containing ADH $200 \mu \mathrm{U} / \mathrm{ml}$ and $5 \mathrm{mM}$. [K $\mathrm{K}^{+}$followed by a prolonged $\left(90 \mathrm{~min}\right.$ ) exposure to $20 \mathrm{mM}\left[\mathrm{K}^{+}\right]$. Tubular fluid samples were obtained continuously during this final period.

Effect of CAMP on the hydroosmotic response. The effect of 8-parachlorophenylthio-cyclic adenosine monophosphate (8-p-CPT-cAMP) (Sigma Chemical Company, St. Louis, MO) on the hydroosmotic response in $\mathrm{CCT}$ from five $\mathrm{KD}$ and four $\mathrm{C}$ rabbits was determined by using a $200 \mathrm{mOsm} / \mathrm{kg} \mathrm{H} \mathrm{H}_{2} \mathrm{O}$ transepithelial gradient at $25^{\circ} \mathrm{C}$. Tubules were allowed to equilibrate for $150 \mathrm{~min}$ before exposure to bath containing 8-p-CPT-cAMP in concentrations of $10^{-6}, 10^{-5}$, and $10^{-4}$ $M$. Three samples were then collected during each period for determination of the rate of water absorption (Jv) and hydraulic conductivity coefficient (Lp).

Effect of phosphodiesterase inhibition by isobutylmethylxanthine (IBMX) on the ADH-induced hydroosmotic response. The maximal hydroosmotic response of $\mathrm{CCT}$ from four $\mathrm{KD}$ and four $\mathrm{C}$ rabbits was evaluated using $\mathrm{ADH}(200 \mu \mathrm{U} / \mathrm{ml})$ at $25^{\circ} \mathrm{C}$ in the absence and presence of isobutylmethylxanthine (IBMX) (Sigma Chemical Co.) $\left(10^{-4} \mathrm{M}\right)$. In addition, CCT from three $\mathrm{KD}$ rabbits were perfused as above except that IBMX was present in a concentration of $10^{-3} \mathrm{M}$. Otherwise, tubules were perfused according to the same conditions and protocol as outlined in the previous sections.

Effect of forskolin. A dose response curve for forskolin (Calbiochem, La Jolla, CA) using bath concentrations of $10^{-6}, 10^{-5}$, and $10^{-4} \mathrm{M}$ was determined in CCT from five $\mathrm{KD}$ and four $\mathrm{C}$ rabbits at $25^{\circ} \mathrm{C}$. Since forskolin was initially dissolved in propylene glycol before addition to the normal bath solution, a control period using a $1.25 \%$ bath solution of propylene glycol without forskolin (the concentration present with $10^{-4} \mathrm{M}$ forskolin) was added to the protocol. The hydraulic conductivity was no different in the presence of propylene glycol compared with the normal control period.

Calculations and statistics. $\mathrm{Jv}\left(\mathrm{nl} \cdot \mathrm{mm}^{-1} \cdot \mathrm{min}^{-1}\right)$ and $\mathrm{Lp}\left(\mathrm{cm} \cdot \mathrm{s}^{-1}\right.$. atm $^{-1} \cdot 10^{-7}$ ) were calculated according to the following formulas:

$J v=V_{L}\left[\left(C_{L} / C_{0}\right)-1\right] / L$,

where $V_{L}$ is the rate of tubular fluid collection, $L$ is the length of the tubule, and $C_{L}$ and $C_{o}$ are the concentrations of ${ }^{14} \mathrm{C}$ in the collected and perfused fluid, respectively. The rate of perfusion, $\mathrm{V}_{\mathrm{o}}$, averaged $10.84 \pm 0.50 \mathrm{nl} \cdot \mathrm{min}^{-1}$ and was calculated at $V_{o}=\left(C_{L} / C_{o}\right) V_{L}$.

$$
\begin{aligned}
& L p=\frac{1}{\operatorname{RTSC}_{b}^{2}}\left\{C_{b}\left(V_{o}-V_{L}\right)\right. \\
& \left.+\left[C_{o} V_{o} \ln \left(C_{b}-C_{o}\right) V_{o}-\ln \left(C_{b} V_{L}-C_{o} V_{o}\right)\right]\right\},
\end{aligned}
$$

where $C_{b}$ and $C_{o}$ are the osmolalities of the bath and perfusate, respectively; $R$ is the gas constant; $T$ is the absolute temperature; and $S$ is the luminal surface area, calculated from an assumed mean internal tubular diameter of $20 \times 10^{-4} \mathrm{~cm} \mathrm{(22).}$

The results are expressed as mean \pm 1 SEM; $N=$ number of animals or tubules. The results from control and experimental animals and tubules were compared using Student's $t$ test for unpaired data and analysis of variance for repetitive measurements of paired observations in the same animal or in the same tubule.

\section{Results}

$A D H$ dose response. The average values of $\mathrm{Lp}$ at the various concentrations of ADH are shown in Fig. 3. The ADH-induced $\mathrm{Lp}$ in CCT from six $\mathrm{KD}$ rabbits was significantly less than that for CCT from four $\mathrm{C}$ rabbits at all concentrations of $\mathrm{ADH}$ tested and represented approximately a 55\% decrease in responsiveness. There was no significant difference between the two groups with respect to basal Lp. Furthermore, analysis of 


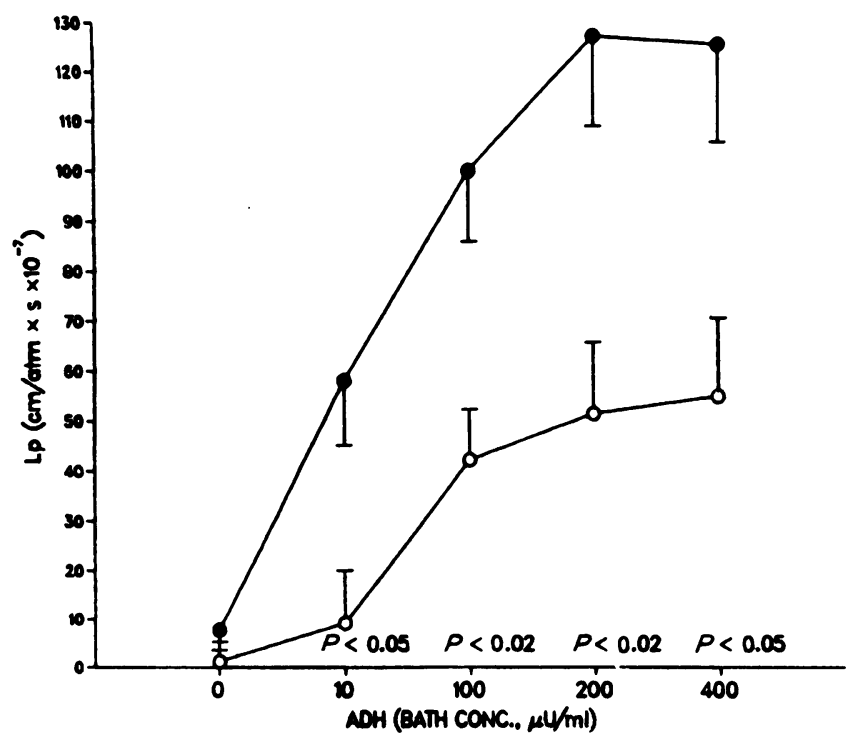

Figure 3. Effect of ADH on the hydraulic conductivity coefficient, $\mathrm{Lp}$, in cortical collecting tubules from four control (๑) and six KD (o) rabbits.

variance showed that there was no difference between the $\mathrm{Lp}$ obtained with ADH bath concentrations of 100,200 , and 400 $\mu \mathrm{U} / \mathrm{ml}$. Therefore, a bath concentration of $200 \mu \mathrm{U} / \mathrm{ml}$ was used as the maximal stimulatory concentration in subsequent experiments.

Maximal $A D H$ response. The maximal $\mathrm{Jv}$ and $\mathrm{Lp}$ with $200 \mu \mathrm{U} / \mathrm{ml}$ of $\mathrm{ADH}$ were determined at $37.5^{\circ} \mathrm{C}$ in CCT from four $\mathrm{C}$ and four $\mathrm{KD}$ animals (Fig. 4). The mean $\mathrm{Jv}$ of $3.24 \pm 0.78 \mathrm{nl} \cdot \mathrm{mm}^{-1} \cdot \mathrm{min}^{-1}$ for control animals was significantly greater $(P<0.05)$ than that obtained from $\mathrm{KD}$ animals, $0.83 \pm 0.19 \mathrm{nl} \cdot \mathrm{mm}^{-1} \cdot \mathrm{min}^{-1}$. Furthermore, the Lp was significantly greater for the control than the experimental group, $192.3 \pm 49.7$ vs. $44.4 \pm 10.9 \mathrm{~cm} \cdot \mathrm{s}^{-1} \cdot \mathrm{atm}^{-1} \cdot 10^{-7}$, respectively $(P<0.05)$.

Reflection coefficient of $\mathrm{NaCl}$ vs. raffinose. The reflection

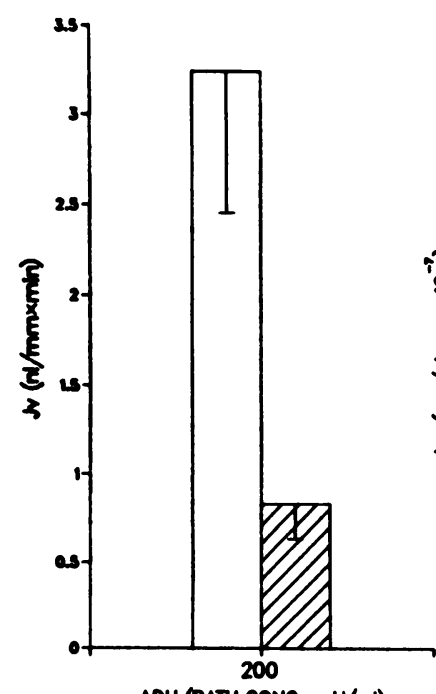

AOH (BATH CONC., MU/mi)

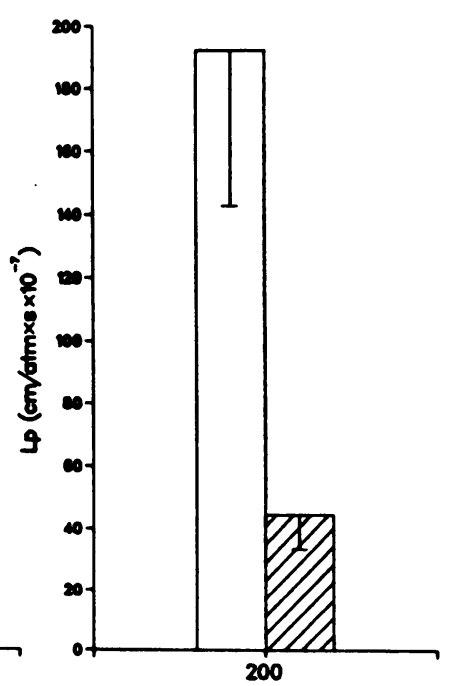

АDH (BATH CONC. $\mu / / / m)$
Figure 4. Maximal ADH-stimulated net water flux and hydraulic conductivity coefficient in CCT from four C (口) and four KD (m) rabbits. The Jv and Lp were significantly decreased $(P<0.05)$ in tubules from potassium depleted rabbits.

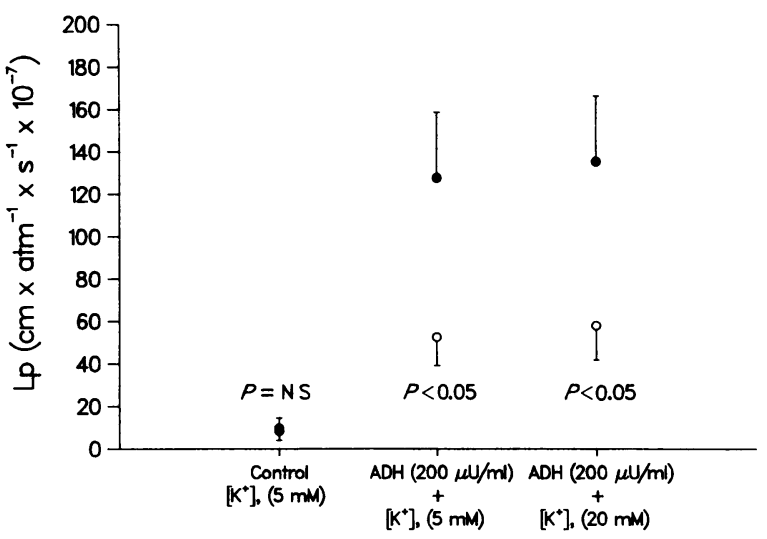

Figure 5. Effect of a high peritubular $\mathrm{K}^{+}$concentration on ADHstimulated hydraulic conductivity in CCT from four C (๑) and six KD (o) rabbits.

coefficient for $\mathrm{NaCl}$ was estimated from the ratio of the $\mathrm{Jv}$ obtained with $\mathrm{NaCl}$ to that obtained with raffinose, assuming a reflection coefficient of one for the latter. The tubules were perfused according to the methods outlined earlier with the addition of $\mathrm{ADH} 200 \mu \mathrm{U} / \mathrm{ml}$ at $25^{\circ} \mathrm{C}$. The ratio of $\mathrm{Jv}(\mathrm{NaCl}) /$ $\mathrm{Jv}$ (raffinose) was 0.91 , which is similar to the value reported previously for CCT obtained from normal animals and studied under similar conditions (23). These results suggest that the decreased hydroosmotic response in tubules from KD animals is not due to increased permeability to sodium chloride.

Effect of elevated peritubular $K^{+}$concentration. The maximally stimulated $\mathrm{Lp}$ with a bath $\left[\mathrm{K}^{+}\right]$of $20 \mathrm{mM}$ remained significantly reduced in CCT from six $\mathrm{KD}$ rabbits compared with four $\mathrm{C}$ rabbits (Fig. 5). There was no difference between the two groups with respect to basal hydraulic conductivity.

Effect of 8-p-CPT-cAMP. The average Lps at the various concentrations of 8-p-CPT-cAMP are shown in Fig. 6. There was no difference between the two groups at any of the concentrations tested. The basal hydraulic conductivity was not different between the two groups.

Effect of phosphodiesterase inhibition. The maximal Lp both before and after the addition of IBMX to bath containing

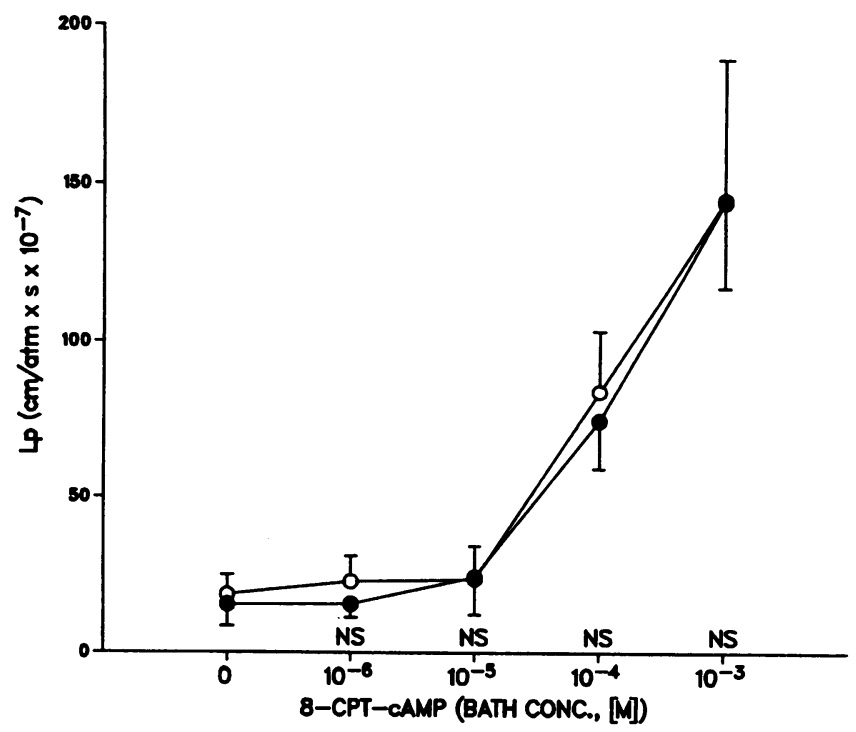

Figure 6. Effect of 8-p-CPT-cAMP on the hydraulic conductivity coefficient in CCT from four control (๑) and five $\mathrm{KD}(0)$ rabbits. 
ADH $(200 \mu \mathrm{U} / \mathrm{ml})$ is shown in Fig. 7. The Lp increased significantly from 88.06 to $130.22(P<0.005)$ in tubules from four control rabbits and from $26.82 \pm 12.00$ to $60.17 \pm 16.98$ $\mathrm{cm} \cdot \mathrm{s}^{-1} \cdot \mathrm{atm}^{-1} \cdot 10^{-7}(P<0.01)$ in tubules from four $\mathrm{KD} \mathrm{rab}-$ bits. Although an increase in hydraulic conductivity was observed, the overall hydroosmotic response of tubules from $\mathrm{KD}$ rabbits was still significantly reduced when compared with control tubules $(P<0.025)$. In addition, the $\mathrm{Lp}$ in CCT from three $\mathrm{KD}$ rabbits using IBMX at $10^{-3} \mathrm{M}$ was no different from that at $10^{-4} \mathrm{M}, 50.35 \pm 8.22$ vs. $60.17 \pm 16.98$, respectively.

Effect of forskolin. The forskolin dose response curve is shown in Fig. 8. Although $\mathrm{Lp}$ in response to forskolin was somewhat greater in CCT from five $\mathrm{KD}$ rabbits compared with four $\mathrm{C}$ rabbits, this difference did not reach statistical significance. The addition of isobutylmethylxanthine to the highest concentration of forskolin had no additional effect on hydraulic conductivity.

\section{Discussion}

The present study demonstrates that potassium deficient rabbits develop a urinary concentrating defect similar to that described in previous human and animal studies $(2,3,8,24,25)$. This concentrating defect seems to develop independently of the polydipsic state as both the ad-libitum and water-controlled intake groups showed no difference with respect to either the magnitude of their potassium depletion or the severity of their decreased concentrating ability. In addition, this nephrogenic resistance to antidiuretic hormone is completely normalized after only 1 wk of potassium repletion, a finding that is consistent with previous work by Rubini et al. (26) in humans. Furthermore, the lack of improvement of the concentrating defect after DOCA administration contrasts with the significant improvement shown in adrenalectomized rabbits after DOCA treatment (27), thus suggesting that coexistent hypoaldosteronism is not a major cause of the decreased concentrating ability in the $\mathrm{KD}$ rabbits.

The in vitro perfusion experiments with $\mathrm{ADH}$ at $25^{\circ} \mathrm{C}$ and $37.5^{\circ} \mathrm{C}$ suggest that the state of nephrogenic diabetes insipidus associated with $\mathrm{KD}$ may be partially secondary to a relative insensitivity of the CCT to the hydroosmotic effects of $\mathrm{ADH}$. The ADH dose response profile is indicative of a decreased $V_{\max }$ of the ADH stimulated adenylate cyclase system. The significant reduction in the hydraulic conductivity of this

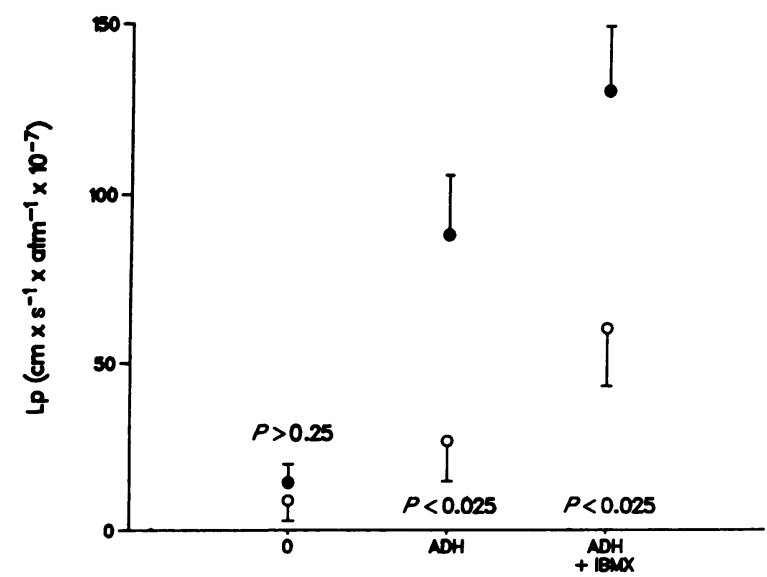

Figure 7. Effect of isobutylmethylxanthine, $10^{-4} \mathrm{M}$, on the ADHstimulated hydraulic conductivity coefficient in CCT from four C (•) and four $\mathrm{KD}(\mathrm{O})$ rabbits.

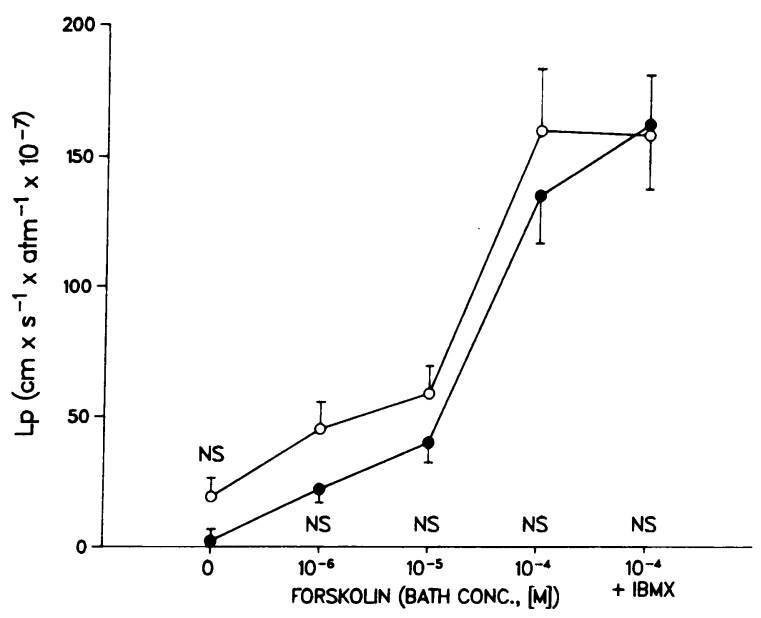

Figure 8. Effect of forskolin on the hydraulic conductivity coefficient in CCT from four $\mathrm{C}(\bullet)$ and five $\mathrm{KD}(0)$ rabbits. IBMX, $10^{-4} \mathrm{M}$, had no effect on the maximal forskolin stimulated hydraulic conductivity.

nephron segment may contribute to the decreased renal papillary solute content shown in this and other studies $(4,27)$ and, ultimately, to the reduction in urinary concentrating ability. According to current thoughts on the mechanisms of urinary concentration $(28,29)$, water reabsorption in the CCT in the absence of urea reabsorption results in a progressive increase in luminal urea concentration before reaching the inner medulla. The higher urea permeability of the inner medullary collecting duct then allows urea to be reabsorbed down a favorable concentration gradient resulting in an increased interstitial urea concentration. However, if as found in this study, decreased water reabsorption occurred in the cortical collecting tubule, this would result in a decreased luminal urea concentration in the inner medullary collecting duct, and hence, decreased urea reabsorption. Subsequently, this would contribute to a decrease in passive water abstraction by the thin descending limb of Henle, which would secondarily result in decreased passive sodium chloride reabsorption by the thin ascending limb of Henle. Thus, this sequence of alterations of water, sodium chloride, and urea reabsorption would result in a decreased interstitial solute concentration and, ultimately, a decreased maximal urine osmolality. Furthermore, although the issue is not addressed in this study, it is possible that decreased sodium chloride reabsorption in the thick ascending limb of Henle may also play a role in the concentrating defect $(30,31)$.

The experiments using 8-p-CPT-cAMP, IBMX, and forskolin were performed to better define the mechanisms of decreased $A D H$ responsiveness of $C C T$ from $K D$ rabbits. The normal hydroosmotic response to 8-p-CPT-cAMP suggests that this cAMP analogue can bypass the defect and is compatible with the hypothesis that decreased intracellular cAMP accumulation is a major determinant of the reduced ADH response. The contribution of cAMP degradation from phosphodiesterase activity was evaluated using IBMX, a potent phosphodiesterase inhibitor that, in a concentration of $10^{-3} \mathrm{M}$, has been shown to maximally inhibit this enzyme (32). Although the relative augmentation of the hydroosmotic response to $\mathrm{ADH}$ in the presence of IBMX was greater in the $\mathrm{KD}$ group than in controls, $\mathrm{Lp}$ was still significantly reduced in the $\mathrm{KD}$ group, thus suggesting that phosphodiesterase activity is not a major factor in this abnormal response. Also relevant to this argument are recent studies by Kim et al. (12) showing that phosphodi- 
esterase activity was not elevated in inner medullary collecting ducts from $\mathrm{KD}$ rats. The present study also shows that forskolin is able to bypass the defective step(s) and that adenylate cyclase can be activated equally in $\mathrm{KD}$ and $\mathrm{C} \mathrm{CCT}$. Interestingly, unlike the ADH experiments, IBMX produced no augmentation of the hydroosmotic response to forskolin. The exact reason for this is unclear but several possibilities exist. First, although ADH and forskolin were present in maximally stimulatory concentrations, their modes of activation of adenylate cyclase differ significantly $(32,33)$. Second, ADH stimulates negative modulators of its own action (e.g., prostaglandin $\mathrm{E}_{2}$ ) (16), which may act to increase phosphodiesterase activity and thus explain why IBMX augments the hydroosmotic response to ADH. Finally, the relative effect of phosphodiesterase activity may be diminished by the fact that forskolin is a much more potent stimulant of adenylate cyclase activity than agents that require the guanine nucleotide regulatory protein for activation of adenylate cyclase (33).

Collectively, these data suggest that the decreased $\mathrm{ADH}$ responsiveness of $\mathrm{CCT}$ from $\mathrm{KD}$ rabbits is due to a defect at or proximal to activation of the catalytic subunit of adenylate cyclase. However, the precise mechanism of this defect remains to be elucidated.

\section{Acknowledgments}

We thank Jill Scotch for her secretarial assistance in the preparation of this manuscript and Dr. Robert Kunau for his encouragement and helpful discussions.

This work was supported in part by National Institutes of Health Training Grant AM07103, Program Project Grant AM17387, Institutional Research Grant 2 SO7-RR05654-16, and The Medical Research Service of the Veterans Administration.

\section{References}

1. Ragan, C., J. W. Ferrebee, P. Phyfe, D. W. Atchley, and R. F Loeb. 1940. A syndrome of polydipsia and polyuria induced in normal animals by desoxycorticosterone acetate. Am. J. Physiol. 131:73-78.

2. Hollander, W., R. W. Winters, T. F. Williams, J. Bradley, J. Oliver, and L. G. Welt. 1957. Defect in the renal tubular reabsorption of water associated with potassium depletion in rats. Am. J. Physiol. 189(3):557-563.

3. Kleeman, C. F., and M. H. Maxwell. 1959. Contributory role of extrarenal factors in the polyuria of potassium depletion. $N$. Engl. J. Med. 260:268-273.

4. Manitius, A., H. Levitin, D. Beck, and F. H. Epstein. 1960. On the mechanism of impairment of renal concentrating ability in potassium deficiency. J. Clin. Invest. 39:684-694.

5. Galvez, O. G., W. H. Bay, B. W. Roberts, and T. F. Ferris. 1977. The hemodynamic effect of potassium deficiency in the dog. Circ. Res. 40(Suppl I.)11-16.

6. Smith, S. G., and T. Lasater. 1950. A diabetes insipidus-like condition produced in dogs on potassium-deficient diet. Proc. Soc. Exp. Biol. Med. 74:427a. (Abstr.)

7. Kannegiesser, H., and J. B. Lee. 1971. Role of outer medullary metabolism in the concentrating defect of $\mathrm{K}^{+}$depletion. Am. J. Physiol. 220:1701-1707.

8. Rutecki, G. W., J. W. Cox, G. W. Robertson, L. L. Francisco, and T. F. Ferris. 1982. Urinary concentrating ability and antidiuretic hormone responsiveness in the potassium-depleted dog. J. Lab. Clin. Med. 100:53-60.

9. Beck, N., and S. K. Webster. 1976. Impaired urinary concentrating ability and cyclic AMP in $\mathrm{K}^{+}$-depleted rat kidney. Am. J. Physiol. 231: 1204-1208.

10. Carney, S., B. Rayson, and T. Morgan. 1976. A study in vitro of the concentrating defect associated with hypokalemia and hypercalcemia. Pfluegers Arch. Eur. J. Physiol. 366:11-17.

11. Kim, J. K., B. A. Jackson, R. M. Edwards, and T. Dousa. 1982. Effect of potassium depletion on the vasopressin-sensitive cyclic AMP system in rat outer medullary tubules. J. Lab. Clin. Med. 99: 29-38.

12. Kim, J. K., S. N. Summer, and T. Bell. 1984. The cyclic AMP system in the inner medullary collecting duct of the potassium-depleted rat. Kidney Int. 26:384-391.

13. Finn, A. L., J. S. Handler, and J. Orloff. 1966. Relation between toad bladder potassium content and permeability response to vasopressin. Am. J. Physiol. 210:1279-1284.

14. Grantham, J. J., and M. B. Burg. 1966. Effect of vasopressin and cAMP on permeability of isolated collecting tubules. Am. J. Physiol. 211:255-259.

15. Knepper, M., and M. Burg. 1983. Organization of nephron function. Am. J. Physiol. 244:F579-F589.

16. Kirschenbaum, M. A., A. G. Lowe, W. Trizna, and L. G. Fine. 1982. Regulation of vasopressin action by prostaglandins. J. Clin. Invest. 70:1193-1204.

17. Grantham, J. J., and J. Orloff. 1968. Effect of prostaglandin $E_{1}$ on the permeability response of the isolated collecting tubule to vasopressin, adenosine 3',5'-monophosphate and theophylline. J. Clin. Invest. 47:1154-1161.

18. Toback, F. G., N. G. Ordonez, S. L. Bortz, and B. H. Spargo. 1976. Zonal changes in renal structure and phospholipid metabolism in potassium-deficient rats. Lab. Invest. 34:115-124.

19. Burg, M., J. Grantham, M. Abramow, and J. Orloff. 1966. Preparation and study of fragments of single rabbit nephrons. Am. J. Physiol. 210:1293-1298.

20. McKinney, T. D., and P. Myers. 1980 . Bicarbonate transport by proximal tubules: effect of parathyroid hormone and dibutyryl cyclic AMP. Am. J. Physiol. 238:F166-F174.

21. McKinney, T. D., and M. B. Burg. 1978. Bicarbonate absorption by rabbit cortical collecting tubules in vitro. Am. J. Physiol. 234:F141F145.

22. DuBois, R., A. Verniory, and M. Abramow. 1976. Computation of the osmotic water permeability of perfused tubule segments. Kidney Int. 10:478-479.

23. Schafer, J. A., and T. E. Andreoli. 1972. The effect of antidiuretic hormone on solute flows in isolated mammalian collecting tubules. J. Clin. Invest. 51:1279.

24. Berl, T., S. L. Linas, G. A. Aisenbrey, and R. J. Anderson. 1977. On the mechanism of polyuria in potassium depletion. The role of polydipsia. J. Clin. Invest. 60:620-625.

25. Takamitsu, Y., and R. T. Kunau. 1982. Effect of indomethacin on papillary solute content in the potassium-deficient rat. Am. Soc. Neph. 175a. (Abstr.)

26. Rubini, M. E. 1961. Water excretion in potassium-deficient man. J. Clin. Invest. 40:2215-2224.

27. Schwartz, M. J., and J. P. Kokko. 1980. Urinary concentrating defect of adrenal insufficiency. J. Clin. Invest. 66:234-242.

28. Kokko, J. P., and F. C. Rector. 1972. Countercurrent multiplication system without active transport in inner medulla. Kidney Int. 2:214.

29. Stephenson, J. L. 1972. Central core model of the renal counterflow system. Kidney Int. 2:85.

30. Luke, R. G., F. S. Wright, N. Fowler, M. Kashgarian, and G. H. Giebisch. 1978. Effects of potassium depletion on renal tubular chloride transport in the rat. Kidney Int. 14:414-427.

31. Gutsche, H. U., L. N. Peterson, and D. Z. Levine. 1984. In vivo evidence of impaired solute transport by the thick ascending limb in potassium-depleted rats. J. Clin. Invest. 73:908-916.

32. Hall, D. A., L. D. Barnes, and T. P. Dousa. 1977. Cyclic AMP in action of antidiuretic hormone: effects of exogenous cyclic AMP and its new analogue. Am. J. Physiol. 232:F368-F376.

33. Seamon, K., and J. W. Daly. 1981. Activation of adenylate cyclase by the diterpene forskolin does not require the guanine nucleotide regulatory protein. J. Biol. Chem. 256:9798-9801. 